\title{
Effects of African Bentonite on Feed Mycotoxigenic Fungi and Growth of African Catfish Clarias gariepinus
}

\author{
Uchechukwu Dennis Enyidi $^{1, *} \mathbb{C}^{\mathbb{C}}$, Blessing Akudo Emeaso ${ }^{1}$
}

${ }^{1}$ Department of Fisheries and Aquatic Resources Management 16 Michael Okpara University of Agriculture Umudike Umuahia Abia State Nigeria.

\section{Article History}

Received 27 April 2020

Accepted 21 September 2020

First Online 23 September 2020

\section{Corresponding Author \\ Tel.: +2348141607067 \\ E-mail: enyidiuche@yahoo.com}

\section{Keywords}

Mycotoxins

Aflatoxin B1

Plant Proteins

Bentonite

Fungi

\begin{abstract}
Feed and feed ingredients in the tropics are prone to attacks of mycotoxigenic fungi (myco-fungi) infestation during storage or from the field. The heat applied in feed production destroys only the myco-fungi leaving mycotoxins that eventually end up in the fish. Mycotoxins have negative effects on the growth of fish. It is plausible to reduce or totally eliminate the mycotoxins and myco-fungi by the inclusion of special African bentonite supplement called 'Uro'. Five iso nitrogenous and iso energetic feed were made with soybean meal of $12 \%$ moisture stored at relative humidity of $78 \%$ and temperature $29.45 \pm 0.87^{\circ} \mathrm{C}$ for 30 days. The feed was labelled as $\mathrm{F} 1$ to $\mathrm{F} 5$ and varied in inclusion levels of bentonite supplement as follows, F1, 34\%, F2, 25\%, F3, 15\%, F4, 5\% and $\mathrm{F} 5,0 \%$. The protein supplement and basal ingredients in the diets were same. Feed ingredients were weighed, mixed, conditioned and pelleted. The feed was dried at $40^{\circ} \mathrm{C}$ for 24 hours and subjected to mycological analysis. African catfish fingerlings of average weight $6.5 \pm 0.36 \mathrm{~g}$ were stocked at 15 fish per three replicate aquaria per feed type. Fish were fed to satiation twice daily for 140 days. The catfish fed with F1(35\% bentonite) had the best food conversion ratio, $1.63 \pm 0.15$, highest SGR $5.7 \pm 0.05 \%$ day 1 , weight gain $45.7 \pm 3.65 \mathrm{~g}$, protein efficiency ratio $1.19 \pm 0.10$ and highest gut weight $3.46 \pm 0.45 \mathrm{~g}$. All growth and nutritional parameters were increasing with increasing inclusion of bentonite. Mycological analyses showed that three myco-fungi, namely Aspergilus flavus, Mucor mucedo and Cladosporium cladosporioides were prevalent in the feed. However, feed 1 to feed 3, were completely free from myco-fungi, while feed 4 had traces of $M$. mucedo and $C$. Cladosporioides but all myco-fungi were prevalent in F5. African bentonite is calcinated and sequestered feed ANF, myco-fungi and mycotoxins. Bentonite increased digesta viscosity which enabled better digestion of feed, lower FCR, enhanced alkaline intestine for protein and fatty acid absorption. Bentonite increased catfish total glycerides and cholesterol but reduced AST and ALT of the catfish
\end{abstract}

\section{Introduction}

African aquaculture production is increasing and Nigeria had a significant increased from 21700 tonnes in 1999, to 316700 tonnes in 2016 (FAO, 2016). The success of aquaculture is majorly dependent on feed quality which accounts for more than half the production cost of fish (Enyidi, Pirhonen, Kettunen and Jouni Vielma, 2017). Soybeans and soybean meal are affected by humidity of storage area (Volenik et al.,
2007, Bartosik et al., 2008). During storage soybeans can either loose moisture (desorb) or gain moisture (adsorb) because of their hygroscopic and this affects the growth of mycotoxigenic fungi (Volenik et al., 2007, Bartosik et al., 2008). However, store keeping of feeds and feed ingredients in humidity above $70 \%$ and hot environment $>28^{\circ} \mathrm{C}$, coupled with global weather change can enhance attack of mycotoxigenic fungi (Csernoch, Ráduly, Szab, Madar, Pócsi and László (2020), fungal growth and subsequent mycotoxin production, these adversely 
affects fish growth and quality (Bennett and Klich 2003). The most popular mycotoxins that contaminate feed and food globally are Aflatoxins, ochratoxins and fumosin (Pietsch, 2019a). Fish flesh can accumulate mycotoxin and some of the previous researches were done on, aflatoxin B1 (AFB1), fumonisin B1 (FB1) (deoxynivalenol) DON (Mirocha, Abbas, Windels and Xie,1989; Pietsch, Kersten, Burkhardt- Holm, Valenta and Dänicke, 2013; Greco, Pardo and Pose, 2015), ochratoxin A (OTA) (El-Sayed and Khalil, 2009; Tschirren, Siebenmann and Pietsch, 2018). The mycotoxins in fish tissues and can influence weight, length, feed intake and survival depending on the species. In fisheries aquaculture and aqua-feed production, there had been sustained interest in the supplementation of fishmeal with plant proteins (Hardy, 2010) and recently insect meals (Stamer, 2015; Henry, Gasco, Piccolo, and Fountoulaki 2015). However, increased use of plant protein materials has spiked the probabilities and risks of mycotoxins in cultured fish. This is because plant proteins and indeed plant based materials are prone to high load of aflatoxin (Lazo and Sierra, 2008; Pietsch, 2019). In aquafeed production the commonly used raw materials are maize, rice, wheat bran, soybean, sunflower seed cake, and cottonseed cake, which are highly susceptible to mycotoxin-producing fungi (Pittet,1998; Reddy, Bhoola, Reddy and Bhoola, 2010). The avenues of myco-fungi infestation and subsequent aflatoxins production could be during field to store processes, feed ingredient procurement and feed processing (Embaby, Awni, Abdel-Galil, El-Gendy, 2015), aqua feed formulation, oil infusion and in some tropical countries open sundrying of pelleted feeds. The use of oil meal like groundnut cake, sunflower meal (Mmongoyo, Wu, Linz, Nair, Mugula, Tempelman, and Strasburg, 2017), and sesame seed meal Enyidi, Pirhonen, Vielma (2014), can as well be sources of contamination (Njobeh, Dutton, Åberg, and Haggblom, (2012); Bryden, 2012). In fish nutrition studies, the most popular mycotoxin is AFB1, this could be due to its ubiquitous nature in the tropics and the medical relevance a most potent hepatotoxin and moreso known human carcinogen (El-Sayed and Khalil 2009). The effects of AFB1on fishes had been carried out by several workers example, on Nile tilapia, Cagauan and Tayaban, (2004); Mahfouz and Sherif, (2015); Hussain, Mateen and Gatlin (2017), Rainbow trout Greco et al., (2015), on Cyprinus carpio, Pepeljnjak, Petrinec, Kovacic and Segvic, (2003). Heat treatments of ingredients and even feeds simply destroy the Myco-fungi organisms, without affecting the mycotoxin which accumulates in fish meal and fish feed (Hutanasu, Sfarti, Trifan, Hutanasu, and Stanciu, 2009; Kitya, Bbosa and Mulogo, 2010). Mycotoxicosis represents a great threat for the aqua-cultured, since stored feed ingredients like soybeans easily become infected during storage. Bentonite supplement is capable of combating the problem of mycotoxin in aquafeed production. Eastern
Nigeria is home to the Igbo people and they have two major types of edible bentonite locally called "Nzu" a type of clay that is white or ashy in color and widely eaten, after heat processing and "Uro"a special type that is hard and flat and colored beige or yellowish beige, some are greenish yellow, also widely eaten after heat processing. Bentonites mostly consists of smectite minerals (montmorillonite) and are found almost everywhere around the globe. Clay has been added in some commercial feed to improve quality. The use of clays as protective measures against aflatoxicosis has been proven beneficial in many animal studies and this result in the advancement in the clay additive research (Fowler, Hashim, Velazquez, Deng, and Bailey, 2014; Carraro De Giacomo, Giannossic, Medicic, Muscarellad, Palazzob, Quaranta, Summac, and Tateoa, 2014). The inclusion of bentonites in animal diets act also as gut protectants (enterosorbents), which rapidly and preferentially bind aflatoxins from the digestive tract and thus reduce the absorption of mycotoxin into the organism (Phillips, 1999; Carraro De Giacomo et al., 2014). In that manner, an adverse effect of aflatoxins on efficiency and liver function is minimized without marked defects in mineral metabolism of the animals (Ellis, 2000; Amany, 2009). In further researches, bentonites were tested in numerous animal feed trials, which included chickens, turkey pouts, ducklings, pigs, lambs, mink, trout, tilapia, dairy cows, and goats (Murray, 1991, 2000; Safaei Katouli, Boldaji, and Hassani 2010; Indresh, Devegowda, Ruban, and Shivakumar, 2013).

The purpose of this work is to investigate the effects of using soybean purchased from open markets at Enugu Nigeria, of $12 \%$ moisture content, stored for a month at relative humidity of $78 \%$ and temperature $38^{\circ} \mathrm{C}$ in producing fish feed. Note that storage of soybean can enhance mycotoxigenic fungi vegetation and mycotoxin production. The feed varied in inclusion levels of bentonite supplement so as to examine its effects on possible soybean mycotoxigenic field fungi and mycotoxins availability in the feeds and their growth effects on $C$. gariepinus.

\section{Materials and Methods}

\section{Experimental Fish}

Fingerlings of African catfish Clarias gariepinus of average weight $6.5 \pm 0.36 \mathrm{~g}$ were purchased from a commercial farm at Enugu, Enugu state Nigeria and transported in oxygen bags to the wet laboratory of the department of Fisheries and Aquatic Resources Management, of Michael Okpara University of Agriculture Umudike Umuahia Nigeria. The fish were initially stocked at 100 fish per 100 l plastic container. The fish were acclimated for 14 days and latter distributed to plastic aquarium at 15 fish per aquarium. The dimension of the aquarium was $L=70 \mathrm{~cm}, W=40 \mathrm{~cm}$. 
Rearing water was supplied from the university water works. The water parameter was analyzed bi-weekly to ascertain the Temperature using mercury in-glass thermometer, $\mathrm{DO}_{2}$ measured with using Oakton dissolved oxygen meter (D0901), $\mathrm{pH}$ using $\mathrm{pH}$ meter HANNAH (HI198107), turbidity using turbidimetre, nitrite, and ammonia after (Enyidi et al., 2017). The water parameters of the culture system are recorded in Table1.

\section{Procurement and Storage of Soybeans}

The soybeans grains used in this experiment were purchased from grains warehouse and retail depot at New Market Enugu, Enugu State Nigeria. The warehouse is supplied by farmers and wholesalers from Adamawa State Nigeria. The purchased soybean was transported to wet laboratory of Michael Okpara University of Agriculture Umudike Abia State.The soybean grains were dried to $12 \%$ constant wet weight from its initial $18 \%$. This was done by loading some $200 \mathrm{~g}$ sample seed having $160 \mathrm{~g}$ dry weight to and electric oven set at $40^{\circ} \mathrm{C}$ and drying to relative complete dryness and dry weight of $184 \mathrm{~g}$. Autoclaving was done by locally constructed oven with thermostat set at $40^{\circ} \mathrm{C}$. Then drying was adjusting to $12 \%$ wet weight or $176 \mathrm{~g}$ dry weight. The soybean grains were then stored in a plastic bag and stored at dry place at average temperature $29.45 \pm 0.87^{\circ} \mathrm{C}$ measured with mercury in glass thermometer and relative humidity of $78 \%$ measured with a hygrometer. Storage was for a month and the soybean was processed according to methods stipulated in was used in producing the feed.

\section{Experimental Feed Production}

Five isonitrogenous $(37.7 \%$ crude protein) and isoenergetic ( $3720.401 \mathrm{~kJ} \mathrm{~kg}$ gross energy) diets (F1 to F5) were formulated to vary in composition of bentonite supplement as follows F1, (34\%); F2, (25\%); F3, (15\%); $\mathrm{F} 4,5 \%$ and $\mathrm{F} 5,0 \%$. The protein supplements were combinations of $24-30 \%$ fishmeal and $26-30 \%$ soybean meal. All other basal ingredients were equal. The ingredients were weighed with an electronic balance sensitive to $0.0000 \mathrm{~g}$ and mixed according to the formula tabulated in Table 2 . The bentonite supplement was produced by milling solid bentonite obtained from a supplier. The bentonite was added just before the pelleting of the dough. The mixed ingredients were preconditioned at $100^{\circ} \mathrm{C}$ and then pelleted using $2 \mathrm{~mm}$ die. The pelleting machine used was locally fabricated at Enugu industrial market, Tinker Enugu State Nigeria. The pellets were dried at optimal temperature of $40^{\circ} \mathrm{C}$ using electric oven equipped with a thermostat set. The dried pellets were placed in a plastic bag and stored at $-20^{\circ} \mathrm{C}$ till used.

\section{Feeding of Fish and Experimental Layout}

The fish were stocked at three replicates per treatment feed type. The stocking density of the fish was at 15 fish of average weight $6.5 \pm 0.36 \mathrm{~g}$ per replicate aquaria, per feed type. The weighing of the fish was performed with electronic weighing balance sensitive to $0.0000 \mathrm{~g}$. Initial weighing was done in batches per replicate treatment feed. Subsequent weighing was done every two weeks, till the end of the experiment. Weighing of fish was carried out in the morning hours between $8.00 \mathrm{am}$ to $10.00 \mathrm{am}$. Prior to every weighing day, the catfish were not fed 17 hours to the commencement of weighing. The experimental fish were fed to satiation twice a day. Satiation feeding was achieved by allowing fish to eat until feeding activity stopped, with no feed remaining in the tank. Daily feed intake was recorded. The fish were fed to satiation twice daily for 140 days. The aquaria were cleaned daily and water was also changed daily by removing $3 / 4$ of the water and removing faeces and any uneaten food.

\section{Chemical Analyses}

Crude protein was analyzed by Kjeldahl method from freeze dried samples. Crude protein was calculated as $\% N \times 6.25$. The total lipids were measured by chloroform: methanol -extraction at ratio of 2:1. Total lipid was calculated as the weight difference in nonextracted and extracted samples (Enyidi, 2012). Ash content was calculated by burning known amount of freeze dried muscle sample of the catfish in a muffle furnace for 24 hours at $550^{\circ} \mathrm{C}$.

\section{Mycological Analysis of Fish Feed}

For mycological analysis $10 \mathrm{~g}$ of each sample of fish feed were homogenized in a sterile mortar, and mixed well with $10 \mathrm{~mL}$ peptone water. Dicloran rosebengal chloramphenicol media (DRBC) was prepared. DRBC contained $5 \mathrm{~g} / \mathrm{L}$ peptone, $10 \mathrm{~g} / \mathrm{L}$ glucose, $1 \mathrm{~g} / \mathrm{L} \mathrm{KH} 2 \mathrm{PO} 4$,

Table1. Water quality parameters of culture system used in rearing African catfish fingerlings fed with diets F1-F5 varying in composition of bentonite supplement as F1, (34\%); F2, (25\%); F3, (15\%); F4, 5\% and F5, 0\%.

\begin{tabular}{lccccc}
\hline Parameters & $\mathrm{F} 1$ & $\mathrm{~F} 2$ & $\mathrm{~F} 3$ & $\mathrm{~F} 4$ & $\mathrm{F5}$ (control) \\
\hline $\mathrm{DO}_{2}$ & $7.40 \pm 0.58^{\mathrm{b}}$ & $7.05 \pm 0.38^{\mathrm{d}}$ & $7.28 \pm 0.45^{\mathrm{c}}$ & $7.00 \pm 94^{\mathrm{d}}$ & $7.86 \pm 0.85^{\mathrm{a}}$ \\
$\mathrm{Temperature}$ & $25.59 \pm 0.47^{\mathrm{a}}$ & $25.49 \pm 0.48^{\mathrm{a}}$ & $25.33 \pm 0.33^{\mathrm{a}}$ & $25.34 \pm 0.40^{\mathrm{a}}$ & $25.73 \pm 0.50^{\mathrm{a}}$ \\
$\mathrm{pH}$ & $6.39 \pm 0.47^{\mathrm{ns}}$ & $6.25 \pm 0.54^{\mathrm{ns}}$ & $6.36 \pm 0.52^{\mathrm{ns}}$ & $6.28 \pm 0.46^{\mathrm{ns}}$ & $6.05 \pm 0.51^{\mathrm{ns}}$ \\
Nitrite & $124.23 \pm 0.2^{\mathrm{b}}$ & $125.33 \pm 0.6^{\mathrm{b}}$ & $128.33 \pm 0.1^{\mathrm{a}}$ & $128.27 \pm 0.3^{\mathrm{a}}$ & $127.90 \pm 0.3^{\mathrm{a}}$ \\
\hline $\mathrm{DO}_{2} \mathrm{mg} / \mathrm{l}$, Temp. ${ }^{\circ} \mathrm{C}$, Nitrite $\mathrm{mg} / \mathrm{l}$ & & & & &
\end{tabular}


Table 2. Food ingredient and proximate composition of novel experimental diets varying in inclusion of bentonite supplement used in feeding African catfish for 140 days

\begin{tabular}{|c|c|c|c|c|c|}
\hline & F1 & $\mathrm{F} 2$ & F3 & F4 & F5 \\
\hline Bentonite & 34 & 25 & 15 & 5 & 0 \\
\hline Soybean & 26 & 28 & 28 & 30 & 30 \\
\hline Fishmeal & 24 & 28 & 28 & 30 & 30 \\
\hline Corn/Cassava & 4 & 7 & 7 & 7 & 7 \\
\hline Palm oil & 2 & 2 & 2 & 2 & 2 \\
\hline Vitamin C & 1 & 1 & 1 & 1 & 1 \\
\hline Lysine & 4 & 4 & 4 & 4 & 4 \\
\hline Methionine & 4 & 4 & 4 & 4 & 4 \\
\hline Vitamin prmx & 1 & 1 & 1 & 1 & 1 \\
\hline Fillers & 0 & 0 & 10 & 16 & 21 \\
\hline Total & 100 & 100 & 100 & 100 & 100 \\
\hline \multicolumn{6}{|l|}{ Proximate analysis } \\
\hline Proteins (\%) & 37.77 & 37.40 & 37.50 & 38.60 & 38.40 \\
\hline Lipids (\%) & 7.27 & 7.28 & 7.50 & 7.30 & 7.70 \\
\hline Carbohydrates (\%) & 23.47 & 24.82 & 24.98 & 25.12 & 25.27 \\
\hline Fiber $(\%)$ & 3.51 & 1.95 & 2.15 & 2.4 & 2.8 \\
\hline Ash (\%) & 13.45 & 32.29 & 25.22 & 17.85 & 9.95 \\
\hline Moisture (\%) & 12.38 & 7.34 & 8.85 & 9.05 & 9.4 \\
\hline Phytate (mg/kg) & 20.12 & 22.25 & 21.63 & 20.82 & 19.9 \\
\hline Metab, Energy (kj) & 3720.40 & 3717.50 & 3721.60 & 3727.50 & 3740.60 \\
\hline Dry matter (\%) & 87.62 & 92.66 & 91.15 & 90.95 & 90.6 \\
\hline
\end{tabular}

Proximate composition of Vitamin premix per Kg of feed was as follows: Vit.A,4,800000 IU, D ,12000g; K 0.80g; B1,0.40g; B2,1.20g; B12,8.00mg; Folic acid,0.80g; C,100.00g; Biotin,0.06; Choline chloride,80.0g; manganese,10.0g; Iron, $50.0 \mathrm{~g}$; Copper,10g; lodine,0.30g; Cobalt,0.30g; selenium, $0.04 \mathrm{~g}$

$0.5 \mathrm{~g} / \mathrm{L} \mathrm{MgSO} 4$ x 7H2O, $0.1 \%$ Dicloran (0.2 \% in ethanol), $0.025 \mathrm{~g} / \mathrm{L}$ rosebengal, $0.1 \mathrm{~g} / \mathrm{L}$ chloramphenicol, and 15 $\mathrm{g} / \mathrm{L}$ agar. Also Lactophenol cotton blue stain for fungal microscopic examination was prepared for staining according to modified methods of Alniaeem, Ameen, Hatamleh, Bakri (2015). From the homogenised and liquefied sample, $0.1 \mathrm{~mL}$ was plated on DRBC media. The plates were incubated in an incubator in the laboratory at $30{ }^{\circ} \mathrm{C}$ for 7 days (Pitt and Hocking 1997).

\section{Phenotypic Identification of Fungal Isolates}

Morphological characterization of fungi was based on the macro- and microscopic appearance of hyphae and spores of filamentous fungi according to Pitt, (1979); Pitt and Hocking, (1997), Magnoli, Violante, Combina, Palacio and Dalcero (2003); Domsch, Gams, Anderson (2007).

\section{Production and Extraction of Aflatoxins from A. flavus Isolates}

Extraction of aflatoxin produced by $A$. flavus isolates was performed using synthetic medium, Yeast Extract Sucrose Broth (YES; $2 \%$ yeast extract and $20 \%$ sucrose). Spore suspensions of the isolates were prepared and adjusted to approximately $5 \times 106$ spores/mL by use of a hemocytometer. One $\mathrm{mL}$ spore suspension was inoculated into a flask with $50 \mathrm{~mL}$ of sterile YES and incubated at $25{ }^{\circ} \mathrm{C}$ for 7 days. Slides were prepared according to (Beakes, Glockling, and Sekimoto. (2011), by taking material from each colony and staining with
$0.05 \%$ trypanblue in lactophenol. The slides were observed under Digipro-labomed microscope and photographed. Colony counting were done using and illuminated colony counter. The fungi were identified with the help of available fungal identification keys. After incubation, the entire contents were blended and chloroform was added to the broth (1:1) in a flask. The mixture was kept on the shaker for $24 \mathrm{~h}$. Mixtures were separated in separator funnel to an upper layer containing spores and mycelia, and a lower layer containing chloroform and mycotoxins. The chloroform phase was evaporated in a water bath at $50{ }^{\circ} \mathrm{C}$ and kept in a dark dry bottle (Khaddor, Saidi, Aidoun, Lamarti, Tantaoui- Elaraki, Ezziyyani, 2007).

$\mathrm{CFU} / \mathrm{mL}=\mathrm{cfu} / \mathrm{ml}=$ (no. of colonies $\mathrm{x}$ dilution factor)/volume of culture plate.

\section{Analyses of Hemato-Biochemical Parameters}

Hemato-biochemical parameters were carried out to analyze the effects of the diets and the supplements on liver and health of the fish. A total of three fish were randomly selected from each treatment feed tank. Their blood was collected from the caudal vein by using heparinized syringes. The blood was centrifugation at $3,800 \times \mathrm{g}$ for $5 \mathrm{~min}$ and then, samples of blood serum were separated and collected. The serum was stored at $-70{ }^{\circ} \mathrm{C}$ for the analyses of aspartate aminotransferase (AST), alanine aminotransferase (ALT), glucose, total protein (TP), total cholesterol (TC) and triglycerides (TG). These parameters were measured by using chemical analyser (Fuji DRI-CHM 3500i, Fuji Photo Film, Tokyo, Japan). 


\section{Calculations and Statistical Analyses}

The following indices were collected during the experimental period, Specific growth rate (SGR), Feed conversion ratio (FCR), Protein efficiency ratio (PER), Weight gain (WG), percentage survival, HSI, Visceral fat and condition factor were analyzed as follows;

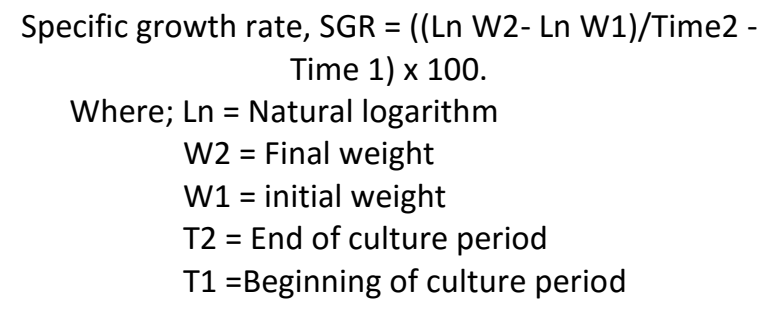

Feed Conversion Ratio FCR

$$
\mathrm{FCR}=\frac{\text { Total weight of feed given }}{\text { weight gained }}
$$

Protein Efficiency Ratio PER

$$
\mathrm{PER}=\frac{\text { Gram live weight gain }}{\text { Grams of protein fed }}
$$

Percentage Survival=initial number-final number $\times 100$

HSI = (liver weight/body weight $) \times 100$

VSI = ((liver + empty gastrointestinal tract + mesenteric fat)/body weight) x 100,

\section{Statistical Analysis}

Results were analyzed using one-way ANOVA and least significant difference (LSD) 0.05 was used in separating possible differences of treatment means. The statistical package used for analyses was SPSS 14.0.

\section{Results}

Mycological analysis showed that Aspergilus flavus at $45 \%$ prevalence was the main myco-fungi species found in the feed samples. There were also very few colonies of Mucor mucedu at $25 \%$ prevalence and Cladosporium cladosporioides at 5\%. However, there were no fungi detected in feed F1, F2 and F3 (Table 3). The highest prevalence of $A$. flavus were detected in F5 and so were other fungi. Results showed constant reduction in the identifiable fungi in the feed as inclusion of bentonite increased. Bentonite inclusion considerable reduced available $A$. Flavus in the diets (Table 3). However, African catfish accepted experimental diets and grew with high specific growth rate (SGR). The best SGR was achieved by those fed with Feed 1 (SGR $5.7 \pm 0.05 \%$ day $^{-1}$ ). The SGR of catfish fed with F1 was significantly higher than those fed with F2, $5.5 \pm 0.13 \% \mathrm{dy}^{-1}$ and F3, $5.3 \pm 0.07 \% \mathrm{day}^{-1}(\mathrm{P}<0.05)$. The catfish fed with F5 had the least SGR $\left(5.1 \pm 0.03 \%\right.$ day $\left.^{-1}\right)$. There were no significant differences $(P>0.05)$ between the SGR of catfish fed with $15 \%$ bentonite (F3) $5.3 \pm 0.07 \%$ day $^{-1}$ and $5 \%$ bentonite (F4) $5.3 \pm 0.04 \%$ day $^{-1}$ (Table 4). Based on these results, the catfish SGR was reducing with reducing inclusion of bentonite supplement. Feed Conversion Ratio (FCR) of the catfish was lowest for those fed with F1 $(1.63 \pm 0.15)$ followed by those fed F2 $(1.93 \pm 0.44)$ respectively. There were no significant differences in the FCR of the catfish fed with the control F5, F3, F4 (2.93 $\pm 0.11,2.93 \pm 0.32,2.70 \pm 0.16)$, ( $P>0.05$ ) (Table 4). The results showed that FCR of the catfish was decreasing with increasing inclusion of bentonite. The catfish weight gain was increasing in line with the increase in SGR. The catfish fed with F1 had the highest weight gain of $45.7 \pm 3.65 \mathrm{~g}$ followed by those fed with F2 (37.16 $\pm 7.57 \mathrm{~g})$. There was however significant difference between the weight gain of catfish fed F1 and those fed F2 $(P<0.05)$. Bentonite supplement enhance the consumption and high weight gain of the catfish. The protein conversion ratio (PCR) and protein efficiency ratios (PER) were best for the catfish fed with highest inclusion of bentonite. There was noticeable significant reduction $(P<0.05)$, in the catfish $P C R$ as the inclusion level of bentonite increased, F1, $(0.63 \pm 0.06), F 2$, $0.76 \pm 0.17$ and F5, (1.15 \pm 0.05$)$ (Table 4). Conversely, there was significant increase in the PER of the catfish as the inclusion level of bentonite increased. Consequently, the PER were as follows; F1, 1.19 \pm 0.10 , $F 2,0.95 \pm 0.14, F 3,0.76 \pm 0.11$ and F5, $0.57 \pm 0.02$ (Table 4). The inclusion of bentonite supplement increased the daily feed intake of the fish as against the control. The increased growth rate associated with high inclusion of bentonite was reflected in the higher weight gain, higher gut weight and gut lengths of fish receiving bentonite supplement (Table 4). The result was evident that catfish waste production ratio (WPR) was highly reduced by inclusion of bentonite. Finally cost of making the feed was lowest for high bentonite diets compared to the diet without bentonite.

Table 3. Prevalence of myco-fungi in novel diets of African catfish varying in composition of bentonite as F1, 34, F2, 25, F3,15, $F 4,5, F 5,0$, used in feeding catfish for140d.

\begin{tabular}{lccccc}
\hline & F1 & F2 & F3 & F4 & F5 \\
\hline Aspergilus flavus & - & - & - & $+(10 \%)$ & $++(45 \%)$ \\
Mucor mucedo & - & - & - & $+(15 \%)$ & $+(25 \%)$ \\
Cladosporium cladosporioides & - & - & - & $-(0 \%)$ & $+(5 \%)$ \\
\hline
\end{tabular}


Table 4. The growth and nutritional performances of African catfish fed diets varying in inclusion of bentonite as follows F1, 35, $\mathrm{F} 2,25, \mathrm{F3}, 15, \mathrm{~F} 4$ 10,F5, 0 for 140 days

\begin{tabular}{|c|c|c|c|c|c|}
\hline Feed & $\mathrm{F} 1$ & $\mathrm{~F} 2$ & F3 & $\mathrm{F} 4$ & F5control \\
\hline Initial av wt & $6.5 \pm 0.36$ & $6.5 \pm 0.36$ & $6.5 \pm 0.36$ & $6.5 \pm 0.36$ & $6.5 \pm 0.36$ \\
\hline Final av wt & $52.22 \pm 3.65^{a}$ & $43.66 \pm 7.57^{b}$ & $38.10 \pm 4.38^{c}$ & $36.03 \pm 2.46^{d}$ & $30.91 \pm 0.86$ \\
\hline Wt gain & $45.7 \pm 3.65^{a}$ & $37.16 \pm 7.57^{b}$ & $31.60 \pm 4.38^{c}$ & $29.53 \pm 2.46^{d}$ & $24.41 \pm 0.86^{e}$ \\
\hline SGR & $5.7 \pm 0.05^{a}$ & $5.5 \pm 0.13^{b}$ & $5.3 \pm 0.07^{c}$ & $5.3 \pm 0.04^{\mathrm{cd}}$ & $5.1 \pm 0.03^{d}$ \\
\hline FCR & $1.63 \pm 0.15^{\mathrm{a}}$ & $1.93 \pm 0.44^{b}$ & $2.93 \pm 0.32^{\mathrm{cd}}$ & $2.93 \pm 0.16^{\mathrm{cd}}$ & $2.70 \pm 0.11^{c}$ \\
\hline PER & $1.19 \pm 0.10^{\mathrm{a}}$ & $0.95 \pm 0.14^{b}$ & $0.76 \pm 0.11^{c}$ & $0.70 \pm 0.04^{c}$ & $0.57 \pm 0.02^{\mathrm{e}}$ \\
\hline PCR & $0.63 \pm 0.06^{d}$ & $0.76 \pm 0.17^{c}$ & $1.22 \pm 0.13^{a}$ & $1.24 \pm 0.07^{a}$ & $1.15 \pm 0.05^{b}$ \\
\hline DFI & $5.13 \pm 0.06^{b}$ & $5.16 \pm 0.01^{b}$ & $5.37 \pm 0.05^{a}$ & $4.90 \pm 0.09^{c}$ & $3.00 \pm 0.00^{d}$ \\
\hline Liver wt & $0.82 \pm 0.27^{c}$ & $0.86 \pm 0.27^{c}$ & $1.08 \pm 0.25^{b}$ & $1.17 \pm 0.05^{a}$ & $0.72 \pm 0.04^{d}$ \\
\hline $\mathrm{HSI}$ & $1.56 \pm 0.43^{e}$ & $1.94 \pm 0.04^{d}$ & $2.89 \pm 0.87^{b}$ & $3.24 \pm 0.05^{a}$ & $2.44 \pm 0.18^{c}$ \\
\hline DMR & $1.58 \pm 0.14^{d}$ & $1.98 \pm 0.45^{c}$ & $2.89 \pm 0.31 a$ & $2.92 \pm 0.16^{a}$ & $2.69 \pm 0.11^{b}$ \\
\hline WPR & $0.53 \pm 0.13^{d}$ & $0.88 \pm 0.40^{c}$ & $1.75 \pm 0.29 a$ & $1.75 \pm 0.14^{a}$ & $1.54 c$ \\
\hline Gut wt & $3.46 \pm 0.45^{a}$ & $2.47 \pm 0.40^{b}$ & $2.07 \pm 0.26^{c}$ & $1.77 \pm 0.79^{d}$ & $1.58 \pm 0.15^{e}$ \\
\hline Fungal count & $1.07 \pm 0.00^{a}$ & $2.03 \pm 0.00^{\mathrm{b}}$ & $2.47 \pm 0.00^{c}$ & $3.63 \pm 0.00^{b}$ & $11.80 \pm 0.00^{e}$ \\
\hline Gut Length & $20.70 \pm 4.77^{c}$ & $15.05 \pm 0.18^{\mathrm{e}}$ & $21.88 \pm 4.31^{b}$ & $22.37 \pm 2.38^{a}$ & $17.26 \pm 2.46^{d}$ \\
\hline Cost/kg & $564.0 \pm 0.00^{d}$ & $529.8 \pm 0.00 c$ & $556.8 \pm 0.00^{b}$ & $636.0 \pm 00^{a}$ & $763.7 \pm 00^{a}$ \\
\hline
\end{tabular}

$1 \$$ USD = N 410 Nigerian Naira. Means not followed by same superscript per row are significantly different $(P<0.05)$.

Table 5. Hemato-biochemical characteristics of African Catfish C. gariepinus Fed for 140 days with diets varying in inclusion levels of bentonite supplement F1,34\%, F2,25\%, F3,15\% F4,5\%, F5,0\%

\begin{tabular}{|c|c|c|c|c|c|}
\hline & F1 & $\mathrm{F} 2$ & $\mathrm{~F} 3$ & $\mathrm{~F} 4$ & F5 \\
\hline AST $(\mu / L)$ & $20.3 \pm 0.01^{a}$ & $33.4 \pm 0.02^{b}$ & $40.4 \pm 0.03^{c}$ & $51.2 \pm 0.01^{d}$ & $78.1 \pm 0.07^{d}$ \\
\hline $\operatorname{ALT}(\mu / L)$ & $20.6 \pm 0.01^{a}$ & $37.3 \pm 0.02^{b}$ & $32.5 \pm 0.01^{b}$ & $48.1 \pm 0.03^{b c}$ & $57.1 \pm 0.06^{c}$ \\
\hline Glucose (mg/dl) & $215.1 \pm 0.02^{\mathrm{a}}$ & $177.4 \pm 0.09^{b}$ & $152.0 \pm 0.06^{c}$ & $133.1 \pm 0.41^{d}$ & $114.1 \pm 0.02^{d}$ \\
\hline Total protein mg/dL & $7.4 \pm 0.07^{n s}$ & $7.2 \pm 0.02^{\mathrm{ns}}$ & $7.0 \pm 0.05^{\mathrm{ns}}$ & $7.5 \pm 0.06^{\mathrm{ns}}$ & $7.0 \pm .0 .07^{\mathrm{ns}}$ \\
\hline Total cholesterol (mg/dL) & $152.0 \pm 0.01^{d}$ & $139.3 \pm 0.02^{d}$ & $118.4 \pm 0.20^{c}$ & $98.3 \pm 0.03^{\mathrm{ab}}$ & $93.3 \pm 0.06^{a}$ \\
\hline Total glycerides (mg/dL) & $125.5 \pm 0.04^{a}$ & $121.4 \pm 0.08^{b}$ & $110.6 \pm 0.09^{a}$ & $110.7 \pm 0.12^{b}$ & $107.5 \pm 0.11^{b}$ \\
\hline Where & & & & & \\
\hline
\end{tabular}

The result of hemato-biochemical analyses showed that the catfish aspertate amino transfarase (AST) was lowest for the catfish fed with feed 1, F1, 20.3 \pm 0.01 $(\mu / L)$. The highest AST value of the catfish was measured from the catfish fed with F5 with value of $78.1 \pm 0.07(\mu / L)$ (Table 5). Based on the results, AST was reducing with increasing inclusion of bentonite supplement. Similarly, the Alanine amino trnsferase (ALT) of the catfishes was highest for the catfish fed with feed F5 $(57.1 \pm 0.06(\mu / L)$. The catfish fed with feed F1 had the lowest ALT of $20.6 \pm 0.01(\mu / L)$. There were significant differences between the ALT of catfish fed with F1 and those fed with F5 $(p<0.05)$. The ALT was decreasing with increasing inclusion of bentonite supplement (Table 5). Conversely the serum glucose value was highest for the catfish fed with feed F1 215.1 $\pm 0.02 \mathrm{mg} / \mathrm{dl}$, but lowest with those fed F5 $114.1 \pm 0.02 \mathrm{mgs} / \mathrm{dl}$. This suggests that glucose level of the catfish was increasing with increasing inclusion of bentonite supplement.

Moreover, the total cholesterol of the catfish fed with $\mathrm{F} 1(152.0 \pm 0.01 \mathrm{mg} / \mathrm{dL})$ was significantly $(P<0.05)$ higher than that of the control feed F5 $(93.3 \pm 0.06$ $\mathrm{mg} / \mathrm{dL}$ ). Like wise the total glycerides of the catfish were highest for those fed with F1, $(125.5 \pm 0.04 \mathrm{mg} / \mathrm{dL})$ while the control fish value (F5 $107.5 \pm 0.11 \mathrm{mg} / \mathrm{dL}$ ) was significantly lowest $(P<0.05)$. The protein content of the fish was constant irrespective of treatment feed. Results show that the total glycerides and cholesterol of the catfish were increasing with increasing inclusion of bentonite in the catfish diet (Table 5).

The cost of producing F1 was much lower for the diets with bentonite than control. Cost of making $1 \mathrm{~kg}$ of F1 was \$ 1.37 USD compared to \$1.87 USD of making F5. Cost was generally increasing reducing inclusion of bentonite supplement. The dry matter ratio (DMR) was reducing with increasing inclusion of bentonite. DMR was similar to waste production ratio. While the lowest was F1, 1.58 \pm 0.14 , the highest was F5.

The highest Dry matter ratio was recorded with the catfish fed with F4 $(2.92 \pm 0.16)$ and the lowest record was for F1 (1.58 \pm 0.14$)$. The DMR of catfish fed with F1 was significantly different $(P<0.05)$ from all other treatments. The highest Waste Production Ratio (WPR) was recorded with the catfish fed with F4 $(1.75 \pm 0.14)$ and the lowest record was for F1 $(0.53 \pm 0.13)$. Waste production was reducing with increasing bentonite 
supplement inclusion. Moreover, there is significantly different $(P<0.05)$ between WPR of catfish fed with F1, F2 and other treatments. The catfish fed with F1 had the highest gut weight $(3.46 \pm 0.45 \mathrm{~g})$, those fed with F5 had the gut weight $(1.60 \pm 0.15 \mathrm{~g})$. There was significant difference between the gt weight of catfish fed with F1 and F5 $(\mathrm{P}<0.05)$.

\section{Discussions}

The most prevalent myco-fungi species identified in the feed was Aspergilus flavus, Mucor mucedo, Cladosporium cladosporioides (Figure 1). It had been noted that $A$. flavus and its mycotoxin aflatoxin B1 (AFB1) is one of the most abundant mycotoxigenic fungi prevalent in fish feed especially in Africa (Marijani, Wainaina, Charo-Karisa, Nzayisenga, Munguti, Gnonlonfin, Kigadye, Okoth. (2017), Pietsch, 2019a, Pietsch, 2019b) The inclusion of African bentonite supplement "Uro"in the feed of African catfish Clarias gariepinus reduced the observable Aspergilus flavus load of the feeds. Bentonite has series of adsorptive surfaces (Figure 2) and had been reported to adsorb and sequester mycotoxins (Diaz, Hagler, Hopkins, and Whitlow, 2002; Bhatti, Shamsul, Bhat, 2017; Rejeb, Antonissen, De Boevre, Detavernier, Van de Velde, De Saeger, Ducatelle, Ayed, and Ghorbal, (2019). The high impact of bentonite supplement in reducing A. flavus prevalence in the feed could also be due to the calcinations of the bentonite. The African type of bentonite "Uro" are usually calcinated during their production process. Calcination of bentonite increases the pore size, adsorbent capacity and subsequently reduction in mycotoxins, compared to control (Rejeb et al., 2019). The SGR were noted to be increasing with increasing inclusion of bentonite. This must have been due to the fact that bentonite reduces mycotoxin in diets. The effects of bentonite in reducing bioavailability of mycotoxin had been noted in previous researches, (Robinson, Johnson, Strey, Taylor, Marroquin-Cardona, Mitchell, Afriyie-Gyawu, Ankrah, Williams, Wang, Jolly,
Nachman, Phillips (2012); Carraro, De Giacomo et al., (2014); Hussain et al. (2017). The intake of mycotoxins from feed to tissue of animals like bird, had previously, been noted to be impeded by inclusion of bentonite (Bhatti, S.A., Khan, M.Z., Hassan, Z.U., Saleemi, M.K., Saqib, M., Khatoon, A, and Akhter, M. (2017). Moreover, mycotoxin absorption by animals have been associated with reduced growth, poor feed efficiency, disease and death in farm animals (Dschaak, et al., 2010; Slamova et al., 2011). The inclusion of bentonite in the diets of African catfish feed could have removed the mycotoxins and other ANF, thereby enhancing fast growth. Bentonite inclusion created alkaline environment in the intestine for absorption of proteins. These enhance absorption and better feed conversion ratio of the fish. Consequently, the chelation of mycotoxins and ANF must have enhanced better FCR and growth of the fish. These findings are similar to previous findings like Phillips et al. (1987) and Eya, Parsons, Haile, Jagidi, and Virginia, (2008), who attributed improved growth performances of rainbow trout fed bentonite to enhanced nutrient utilization. Naturally geophagy is practiced by animals like African catfish. The consumption of clay is popular among some wild animals and human beings in nature and this has been well documented (Hueb, L., Leick, S., Guett, L., Akello, G. and Kutalek, R. (2016). This practice, referred to as geophagy, is the deliberate consumption of soil and clay by both animals and humans (Slamova et al., 2011). Previous studies on the food and feeding habits of the African catfish Clarias gariepinus have reported mud to be about 22-28\% of the diets (Adewumi, Idowu, and Bamisile, (2014), Thomas and Ogamode (2019) 30\% for silver catfish. The improved growth in this study may be attributed to ability of fish to utilise the nutrients in the diet without ANF interference. Bentonite is a very good binder; however, binders are capable of increasing the digesta viscosity through binding of nutrients and other feed constituents (Amirkolaie et al., 2005). The increased digesta viscosity subsequently increased the gut evacuation time. These must have enabled fish to

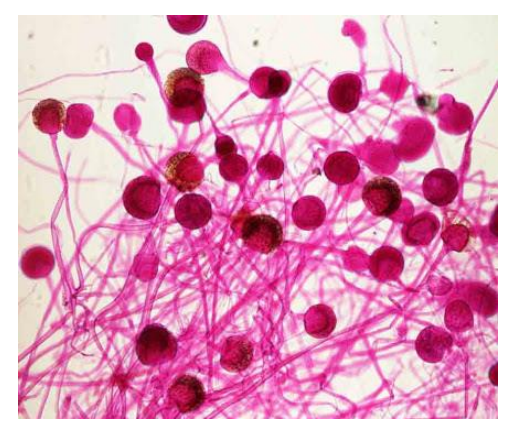

A

Mucor mucedo

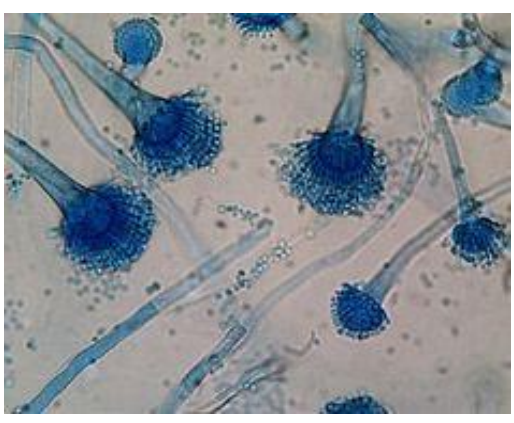

B

Aspergilus flavus

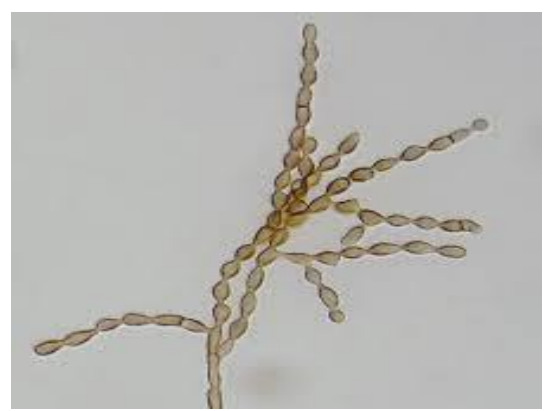

C

Cladosporium cladosporioides

Figure 1. Myco fungi found in novel diets of African Catfish C. gariepinus varying in inclusion levels of bentonite supplement from $34 \%$ of $F 1$ to $0 \%$ of $F 5$. 


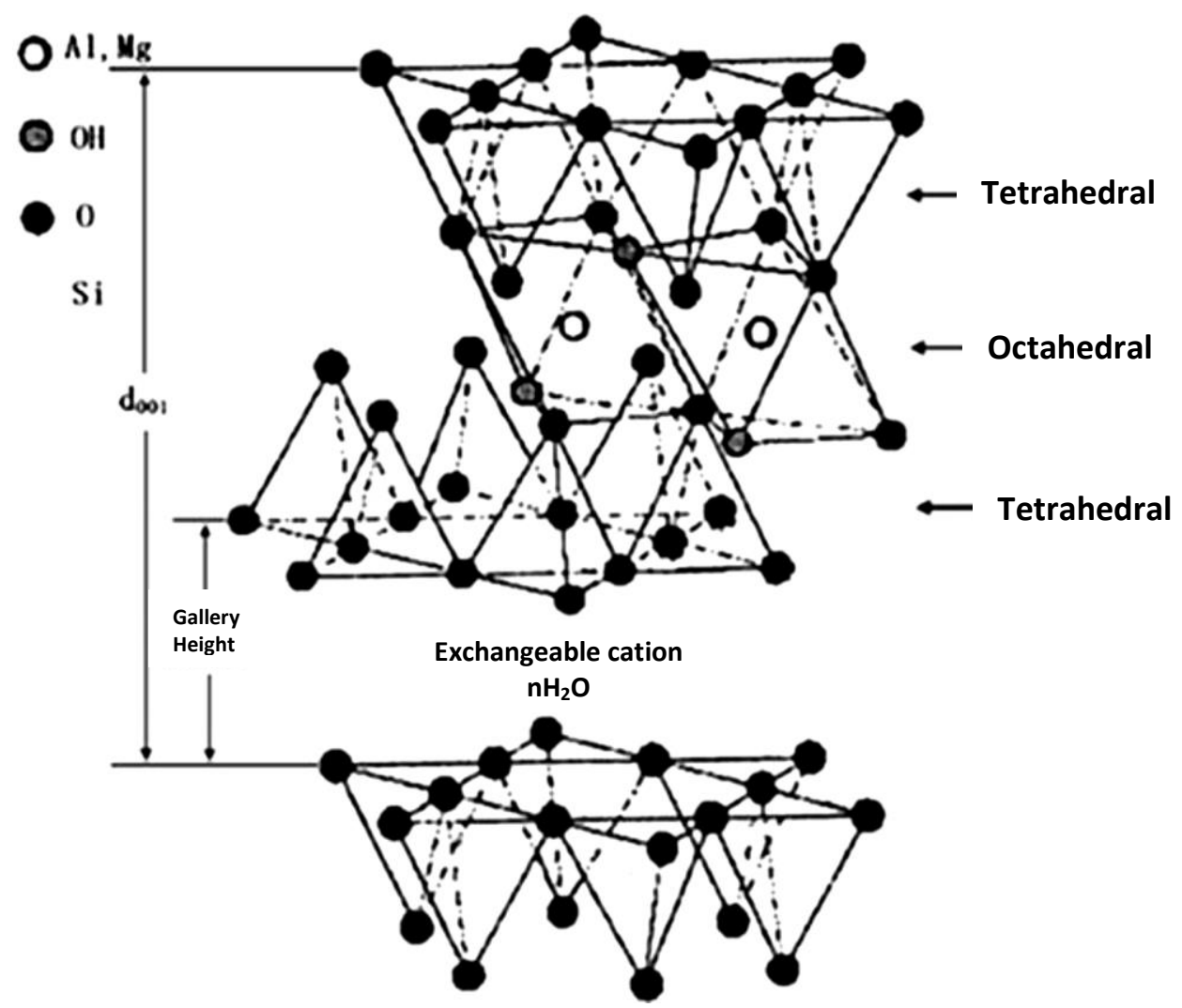

Figure 2. Bentonite folder - physiochemical (Murray, 1991) Structure of bentonite, showing adsorbent points enabling exchange of cations

properly utilise the feed ingredients. Dias et al. (1998) and Danabas and Altun (2011) note that slower increasing gut evacuation time, leads to the improved utilization of nutrients especially protein. The increased evacuation time certainly lead to increased gut weight. As can be seen in the result gut weight and length increased with increment in bentonite supplement. The enhanced utilisation of protein in the diets, due to increased digesta viscosity and evacuation time, were responsible for the high protein efficiency ratio (PER) and low protein conversion ratio (PCR) of the fish with increasing inclusion of bentonite. Hepatosomatic index (HSI), differed significantly $(P<0.05)$ among the treatments. The catfish HSI was notable increasing with increasing inclusion of bentonite supplement. The lowest mean value recorded for the catfish fed with F4 ( $5 \%$ bentonite) diet is within the range recorded for fish with normal health status (Sadekarpawar and Parikh 2013; Wang et al. 2014; Sink and Lochmann 2014). Therefore, the increased values observed in this study with increased quantity of bentonite can be attributed to increased activity of liver during metabolism of diets. Consequently, the increasing, (HSI) of the catfish in this experiment, which is line with similar findings from previous studies (Boonyaratpalin, et al., 1998; Wilson and Castro, 2010; Sadekarpawar and Parikh, 2013). Results show that, high inclusion of bentonite supplement in the diet of catfish reduced the waste production ratio (WPR) (Figure 3 ) and pollution than the control diet (F5). There is significant difference $(P<0.5)$ between WPR of catfish fed with F1 (34\% bentonite) and other treatments. This could be because the high digesta viscosity enabled higher nutrient digestion and lower FCR resulting in lesser waste production. In this present study we noted that at the high inclusion of bentonite supplement, catfish were able to convert their feed very well and utilize their nutrients resulting in lowest waste production than the control diet. The hematobiochemical parameters show that the feed with high bentonite inclusion was not deleterious to the fish. The reduction of mycotoxins in the catfish feed by including bentonite is inline with previous report of Neeratanaphan and Tengjaroenkul (2018) who had similar result by including Thailand bentonite in tilapias feed. This finding is also supported by Diab, Salem, Abeer, Ali, El-Habashi (2018) who noted that values of AST and ALT were increased by mycotoxins and that inclusion of supplements like bentonite reduced the effects in the diets of.

\section{Conclusions}

There are notable benefits in including bentonite supplement in the diets of African catfish. Since cost of producing bentonite feed is much lower than conventional diets. It is recommended to include bentonite in diets of African catfish. The tropics is rife with fungal mycotoxin and these must have accounted 


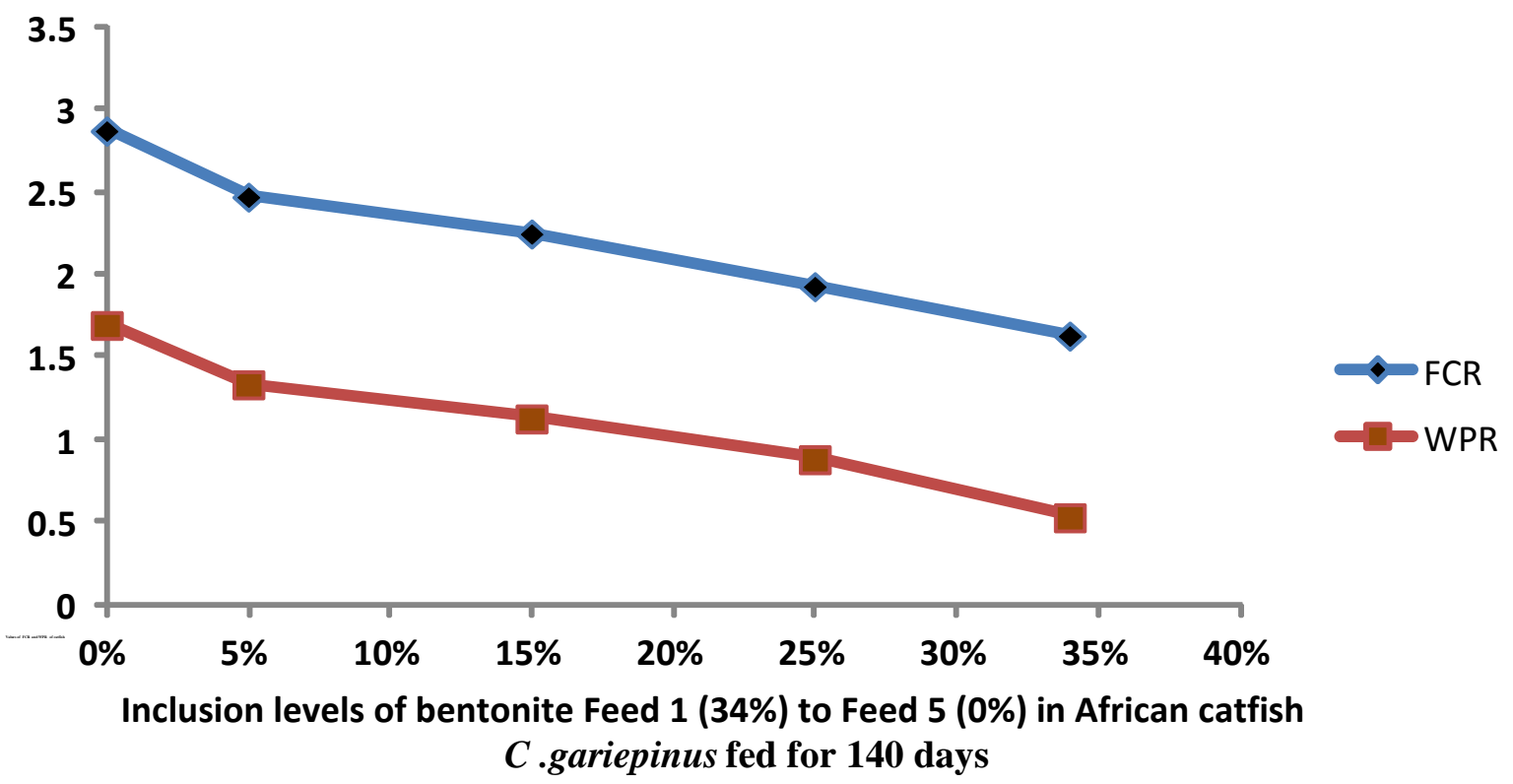

Figure 3. Relationship between feed conversion ratio and waste production ratio of African Catfish C. gariepinus fed with diets varying in inclusion of bentonite supplements as F1,34\% to F5 $0 \%$.

for poor fish production. Therefore, inclusion of bentonite could offer some help in improving fish production.

\section{Acknowledgements}

We are very grateful for the help rendered by staff of Zoology department Michael Okpara University Umudike, Abia state Nigeria, and Department of Microbiology Godfrey Okoye University Emene Enugu, Enugu State Nigeria for help in mycological analysis. We are also grateful for the help of Histology Department staff Mr Agbakwuru for slides and pictures. Thank you very much.

\section{References}

Adewumi, A. A, Idowu, O. E \& Bamisile, S. T. (2014). Food and feeding habits of Clarias gariepinus (Burchell 1822) in Ege Reservior Ekiti State Nigeria. Animal Research International. 11(3): $2041-2047$

de Alencar, E.R., Faroni, L.R. D'A., de Lacerda Filho A.F., Ferreira L.G. Meneghitti M.R. 2006. Lorini, B. Bacaltchuk, H. Beckel, D. Deckers, E. Sundfeld, J. P. dos Santos, J. D. Biagi, J. C. Celaro, L. R. D'A. Faroni, L.de O. F. Bortolini, M. R. Sartori, M. C. Elias, R. N. C. Guedes, R. G. da Fonseca, V. M. Scussel (eds.), Proceedings of the 9th International Working Conference on Stored Product Protection, 15 to 18 October 2006, Campinas, São Paulo, Brazil. Brazilian Post-harvest Association - ABRAPOS, Passo Fundo, RS, Brazil, 2006. (ISBN 8560234004)

Alniaeem S.K, Ameen F, Hatamleh A, \& Bakri M. (2015). Isolation and identification of pathogenic fungi on Oreochromis aureus (Steindachner, 18864). Indian J Geomarine Sci. 44:1213-6.
Amirkolaie, A. K., Leenhouwers, J. I., Verreth, J. A. J. \& Schrama J. W. (2005). Type of dietary fibre (soluble versus insoluble) influences digestion, faeces characteristics and faecal waste production in Nile tilapia. Aquaculture Research, 36, 1157-1166.

Amany, B. (2009). Pathological studies on effects of aflatoxin. Egypt J. Comp. Path \& Clinic. Path Vol 22(1), 179 -193. Applied Clay Science, 6 (1991) 59-68.

Bartosik, R., Rodríguez, J., Cardoso L. 2008. Storage of corn, wheat, soybean and sunflower in hermetic plastic bags. International grain quality \& technology congress Proceedings. Pgs 1-13

Bennett J.W. \& Klich M. (2003). Mycotoxins Clin. Microbiol. Rev., 16 pp. 497-516

Beakes G.W., Glockling S.I., \& Sekimoto S. (2011). The evolutionary phylogeny of comycete fungi. Protoplasma, 249, 3-19.

Bhatti A.A., Shamsul H, \& Bhat, A. R. (2017). Actinomycetes benefaction role in soil \& plant health. Microbial Pathogenesis 111 DOI: 10.1016/j.micpath.2017.09.036

Boonyaratpalin, M., Suraneiranat, O. \& Tunpibal, T. (1998). Replacement of fish-meal with various types of soybean products in diets for the Asian sea bass, Lates calcarifer. Aquaculture, 161: 67-78.

Bryden, W. L. (2012). Mycotoxin contamination of the feed supply chain: Implication of animal productivity and feed security. Animal Feed Science \& Technology 173(s 12):134-158

DOI: 10.1016/j.anifeedsci.2011.12.014

Cagauan A. \& R. Tayaban, R. (2004). "Effect of aflatoxincontaminated feeds in Nile tilapia (Oreochromis niloticus L.)," in Proceedings of the 6th International Symposium on Tilapia Aquaculture, pp. 172-178.

Carraroa A., De Giacomo, A., Giannossic, M.L., Medicic L., Muscarellad, M., Palazzob, L., Quaranta V., Summac, bV, \& Tateoa, F. (2014). Clay minerals as adsorbents of aflatoxin M1 from contaminated milk and effects on milk 
quality. Applied Clay Science Vol.s 88-89, 92-99.

Csernoch, L., Ráduly, Z., Szab, L., Madar, A., Pócsi I. \& László (2020). Toxicological and medical aspects of Aspergillusderived mycotoxins entering the feed \& food chain. Frontiers in Microbiology. 10, 1-23.

Diab A.M., SalemR.M, Abeer, E.M.S., Ali, G.I. E., El-Habashi N. (2018). Experimental ochratoxicosisA in Nile tilapia \& its amelioration by some feed additives. International Journal of Veterinary Science \& Medicine 6, (2), 149-158

Diaz, D.E., Hagler W.M., Hopkins, B.A. \& Whitlow, L.W. (2002). Aflatoxin Binders I: In vitro binding assay for aflatoxin B1 by several potential sequestering agents. Mycopathologia 156: 223-226.

Domsch K.H., Gams W., \& \&erson T. (2007). Compendium of soil fungi. 2nd ed. Eching: IHW-Verlag, 2007. Ellis D, Davis $\mathrm{S}$, Alexiou H, H\&ke R, Bartley R. Descriptions of medical fungi. Adelaide, South Australia: Nexus Print Solutions, 2007.

El-Sayed Y. S. \& Khalil, R. H. (2009). “Toxicity, biochemical effects $\&$ residue of aflatoxin B1 in marine water-reared sea bass (Dicentrarchus labrax L.)," Food \& Chemical Toxicology. 47, (7) 1606-1609.

Ellis R W, Clement M, Tibbetts A \& Winfree, A. (2000) Reduction of a bioavailability of $20 \mu \mathrm{g} / \mathrm{kg}$ alflatoxin in trout fish containing clay. Aquaculture 183: 179-188.

Embaby, E.M., Awni, N.M., Abdel-Galil M.M., \& El-Gendy, H. I. (2015). Prevention and Control Methods of Mycofloa Spoilage Contaminated some Fresh Juices. Current Science International 4: 473-484

Enyidi, U. D. (2012). Production of feeds for African catfish Clarias gariepinus using plant proteins. Jyvaskyla Studies in Biological Sciences, 251. ISBN:978-951-39-4925-9, ISSN: 1456-9701.

Enyidi U., Pirhonen, J. \& Vielma J. (2014). Effects of sesame seed meal and bambaranut meal on growth \& feed utilization \& body composition of Juvenile African catfish Clarias gariepinus. Iranian Journal of Fisheries Science. 13(4), 998-1013

Enyidi U.D., Pirhonen, J., Kettunen J. \& Vielma, J. (2017). Effect of Feed Protein: Lipid Ratio on Growth Parameters of African Catfish Clarias gariepinus after Fish Meal Substitution in the Diet with Bambaranut (Vo\&zeia subterranea) Meal \& Soybean (Glycine max) Meal. Fishes 2017, 2, 1; doi: doi:10.3390/fishes2010001

Eya, J.C., Parsons, A., Haile, I., Jagidi, P. \& Virginia, W. (20080. Effects of Dietary Zeolites (Bentonite \& Mordenite) on the Performance Juvenile Rainbow trout Onchorhynchus myskis. Australian Journal of Basic and Applied Sciences, 2(4): 961-967.

FAO. (2016). The State of World Fisheries \& Aquaculture Contributing to food security \& nutrition for all. Rome. $200 \mathrm{pp}$.

Fowler, J., Hashim, M., Velazquez, A.L.B., Deng, Y. \& Bailey, C.A., 92014). Utilization of a spray-applied calcium bentonite clay to ameliorate the effects of low-levels of aflatoxinin starter broiler diets containing DDGS. Nat. Prod. Chem. Res., 2: 127-130.

Greco, M., Pardo A, \& Pose, G. (2015). Mycotoxigenic fungi \& natural co-occurrence of mycotoxins in rainbow trout (Oncorhynchus mykiss) feeds. Toxins (Basel).7:45954609. DOI: 10.3390/toxins7114595

Hardy, R.W. (2010). Utilization of plant proteins in fish diets: effects of global demand and supplies of fishmeal. Aquaculture Research. 41, 770-776.

Hueb, L., Leick, S., Guett, L., Akello, G. \& Kutalek, R. (2016).
Geophagy in Northern Ug\&a: Perspectives from Consumers and Clinicians. Am J Trop Med Hyg. 95(6): 1440-1449.

Hutanasu, C., Sfarti, C., Trifan, A., Hutanasu, M. \& Stanciu, C. (2009). Aflatoxin contamination of food: additional risk factor for chronic liver diseases. Rev. Med. Chir. Soc. Med. Nat. lasi., 113: 1061-1065

Hussain, D., Mateen, A., \& Gatlin, D.M. III. (2017). Alleviation of aflatoxin B1 (AFB1) toxicity by calcium bentonite clay: Effects on growth performance, condition indices \& bioaccumulation of AFB1 residues in Nile tilapia (Oreochromis niloticus). Aquaculture, 475, 8-15. https://doi.org/10.1016/j.aquaculture.2017.04.003

Indresh, H., Devegowda, G., Ruban, S. \& Shivakumar, M. (2013). Effects of high grade bentonite on performance, organ weights \& serum biochemistry during aflatoxicosis in broilers. Veterinary World. 6(6):313.

Kitya, D., Bbosa G., \& Mulogo, E. M. (2010). Aflatoxin levels in common foods of South Western Ug\&a: A risk factor to hepatocellular carcinoma. European Journal of Cancer Care 19(4):516-21

Khaddor M., Saidi R., Aidoun A., Lamarti A., Tantaoui- Elaraki A., \& Ezziyyani M. (2007). Antibacterial effects \& toxigenesis of Penicillium aurantiogriseum and $P$. viridicatum. Afr J Biotechnol. 2007; 6:2314-8.

Lazo, R.F \& Sierra, G. (2008). Mycotoxin research in humans. Rev Iberoam Micol. 2008 Mar;25(1):7-11.

Magnoli C, Violante, M., Combina, M., Palacio, G. \& Dalcero, A. (2003). Mycoflora and ochratoxin-producing strains of black aspergilli in wine grapes in Argentina. Letters in Applied Microbiology 37: 179-184.

Mahfouz, M.E. \& Sherif, A. H. (2015). A multiparameter investigation into adverse effects of aflatoxin on Oreochromis niloticus health status. The Journal of Basic and Applied Zoology (2015) 71, 48-59

Marijani, E., Wainaina, J.M., Charo-Karisa, H., Nzayisenga, L., Munguti, J., Gnonlonfin, G.J.B., Kigadye, E., \& Okoth, S. (2017). Mycoflora \& mycotoxins in finished fish feed \& feed ingredients from smallholder farms in East Africa Egyptian Journal of Aquatic Research xxx (2017) xxx-xxx

Mirocha, C.J., Abbas, H.K., Windels CE, Xie W. (1989). Variation in deoxynivalenol, 15-acetyldeoxynivalenol, 3acetyldeoxynivalenol, \& zearalenone production by Fusarium graminearum isolates. Applied \& Environmental Microbiology. 55(5):1315-1316.

Mmongoyo, J.A., Wu, F., Linz, J.E., Nair, M. G., Mugula, J.K., Tempelman, R.J., \& Strasburg, G.M. (2017). Aflatoxin levels in sunflower seeds and cakes collected from micro- \& small-scale sunflower oil processors in Tanzania. PLoS One. 2017; 12(4): e0175801.

Murray, H.H. (1991). O v e r v i e w- clay mineral applications. Applied Clay Science, 5, 379-395.

Murray, H.H. (2000). Traditional \& new applications for kaolin, smectite, and palygorskite: a general overview. Applied Clay Science 17, 207-221.

Neeratanaphan L. \& Tengjaroenkul B. (2018). Protective effects of Thai bentonite on aflatoxin B1 contaminated in diet of tilapia fish. Livestock Research for Rural Development. Vol. 30, Article \#152. Retrieved April 22, 2020, http://www.Irrd.org//rrd30/8/teng30152.html

Njobeh P.B., Dutton, M.F., Åberg A.T., \& Haggblom, P. (2012). Estimation of Multi-Mycotoxin Contamination in South African Compound Feeds. Toxins 4(10):836-48 DOI: 10.3390/toxins4100836 
Nomura, H., Ogiso, M., Yamashita M., Takaku, H., Kimura, A., Chikasou, M., Nakamura, Y., Fujii, S., Watai, M. \&Yamada, H. (2011). "Uptake by dietary exposure \& elimination of aflatoxins in muscle and liver of rainbow trout (Oncorhynchus mykiss)," Journal of Agricultural and Food Chemistry, vol. 59, no. 9, pp. 5150-5158.

Pepeljnjak S, Petrinec Z, Kovacic S, \& Segvic, M. (2003). Screening toxicity study in young carp (Cyprinus carpio L.) on feed amended with fumonisin B1. Mycopathologia.156(2):139-145

Pietsch, C, Kersten S, Burkhardt- Holm P, Valenta H. \& Dänicke S. (2013). Occurrence of deoxynivalenol and zearalenone in commercial fish feed: An initial study. Toxins (Basel).5:184-192

Pietsch, C. (2019a). Food Safety: The Risk of Mycotoxin Contamination in Fish. Food Safety: The Risk of Mycotoxin Contamination in Fish DOI: http://dx.doi.org/10.5772/intechopen.89002

Pietsch, C. (2019b). Risk assessment for mycotoxin contamination in fish feeds in Europe. Mycotoxin Research volume 36, 41-62

Pitt, J.I. (1979). The genus Penicellium and its telemorphic states Eupenicellium \& Talaromyces. London: Academic Press, 1979.

Pitt, J.I. \& Hocking, A.D. (1997). Fungi and food spoilage. 2nd Edition, Blackie Academic \& Professional, London.

Phillips T. (1999). Dietary clay in the chemoprevention of aflatoxin-induced disease. Toxicol. Sci. 52:118-126.

Reddy, L., Bhoola, K., Reddy, L. \& Bhoola, K. (2010). Ochratoxins-food contaminants: impact on human health. Toxins 2, 771-779. doi: 10.3390/toxins2040771

Rejeb, R., Antonissen, G., De Boevre, M., Detavernier, C., Van de Velde, M., De Saeger, S., Ducatelle, R., Ayed, M.H. \& Ghorbal, A. (2019) Calcination Enhances the Aflatoxin \& Zearalenone Binding Efficiency of a Tunisian clay. Toxins, $11,602,1-14$.

Robinson A., Johnson N. M., Strey A., Taylor J. F., MarroquinCardona A., Mitchell N. J., Afriyie-Gyawu E., Ankrah N. A., Williams J. H., Wang J. S., Jolly P. E., Nachman R. J., Phillips T. D. (2012). Calcium montmorillonite clay reduces urinary biomarkers of fumonisin $B(1)$ exposure in rats and humans. Food Addit. Contam. A. Chem. Anal. Control Expo. Risk Assess. 2012; 29:809. doi: 10.1080/19440049.2011.651628.

Sadekarpawar S, \& Parikh P. (2013). Gonadosomatic and hepatosomatic indices of freshwater fish Oreochromis mossambicus in response to plant nutrient. World J of Zool.; 1:110-118.

SafaeiKatouli, M., Boldaji, F. \& Hassani S. (2010). Effects of different levels of kaolin, bentonite and zeolite on broilers performances. Journal of Biological Sciences 10, 58-62.
Selim, K. M., El-hofy, H \& Khalil, R. H. (2014). "The efficacy of three mycotoxin adsorbents to alleviate aflatoxin B1induced toxicity in Oreochromis niloticus," Aquaculture International, vol. 22, no. 2, pp. 523-540, 2014.

Sink, T.D. \& Lochmann, R.T. (2014). The Effects of Soybean Lecithin Supplementation to a Practical Diet Formulation on Juvenile Channel Catfish, Ictalurus punctatus: Growth, Survival, Hematology, Innate Immune Activity, \& Lipid Biochemistry. Journal of the World Aquaculture Society Vol.45(2):163-172

Slamova, R., Trckova M., Vondruskova, H., Zraly, Z. \& Pavlik, I. (2011). Clay minerals in animal nutrition. Applied Clay Science, 51, (4), 395-398

Stamer, A. (2015) Insect Proteins-A New Source for Animal Feed. EMBO Reports, 16, 671-768.

Henry, M., Gasco, L., Piccolo, G. \& Fountoulaki E. (2015). Review on the use of insects in the diet of farmed fish: past \& future. Anim. Feed Sci. Technol., 203,1-22, 10.1016/j.anifeedsci.2015.03.001.

Slamova R, Trckova M, Vondruskova H, Zraly Z. \& Pavlik I. (2011). Clay minerals in animal nutrition. Appl Clay Sci.; 51:395-398.

Habold, C., Reichardt, F., Le Maho, Y., Angel, F., Liewig, N., Lignot, J-H \& Oudart, H. (2009). Clay ingestion enhances intestinal triacylglycerol hydrolysis and non-esterified fatty acid absorption. British Journal of Nutritin, 102, 249-257.

Thomas, E., \& Ogamode, O. (2019). Condition Factor, Food \& Feeding Habit of Chrysichthys nigrodigitatus (Siluriformes: Bagridae) from Lower River Benue, Makurdi, Nigeria. Asian Journal of Advances in Agricultural Research, 10(4), 1-7. https://doi.org/10.9734/ajaar/2019/v10i430035

Tschirren, L.; Siebenmann, S. \& Pietsch, C. (2018). Toxicity of Ochratoxin to Early Life Stages of Zebrafish (Danio rerio). Toxins, 10, 264

Volenik M., Rozman V., Kalinovic I., Liska A., Darko Kiš D., Šimić B. 2007. Infl uence of Relative Humidity and Temperature on the Changes in Grain Moisture in Stored Soybean and Maize. Agriculturae Conspectus Scientifi cus | Vol. 72 (2007) No. 3 (215-219)

Wang, L., Liu, W., Lu, K., Xu, W., Cai, D., Zhang, C. \& Qian, Y. (2014). Effects of dietary carbohydrate/lipid ratios on non-specific immune responses, oxidative status and liver histology of juvenile yellow catfish Pelteobagrus fulvidraco. Aquaculture, 426-427, 41-48.

Wilson, J.M. \& Castro, L.F.C., (2010). Morphological diversity of the gastrointestinal tract in fishes. In: Grosell, M., Farrell, A.P. \& Brauner, C.J., (eds). The multifunctional gut of fish. Academic Press is an Imprint of Elsevier, Vol 30, pp1-55. 